\title{
KIRJOITUS
}

VESA NUORVA

\section{Arvot ja merkityksellisyyden kokemus korona-aikana}

Tänä vuonna 2020 on elämän merkityksellisyys noussut uudella tavalla

ـ esille, kun inhimillistä elämää kaikkialla saartava koronavirus on aiheuttanut monenlaisia uudelleenjärjestelyjä. Työnteon päättyessä, toimeentulon heikentyessä ja ihmiskontaktien vähetessä nousevat esiin kysymykset elämän merkityksellisyydestä. Jotkut aiemmin arvokkaina pidetyt asiat ovat menettäneet merkityksensä virustaudin uhatessa terveyden menetyksellä ehkä lopullisesti. Kodin yksinäisyyteen ja hiljaisuuteen pakotetut ovat taas voineet nähdä uudenlaista merkityksellisyyttä asioissa, jotka aiemmin ovat olleet yhdentekeviä.

Tunnetun sanonnan mukaan nykyisin on tärkeämpää se, miten sanotaan tai muuten viestitään kuin se, mitä sanotaan. Viestinnän tapa ja tyyli ovat tärkeämpiä kuin asia, substanssi. Systemaattisen teologian tutkimuksessa kuitenkin haetaan substanssia ja kysytään Lutherin katekismuksesta tuttua kysymystä "mitä se on" mieluummin kuin "miten se tehdään."Merkityksellisyyden etsimiseen kuuluu monia "mitä se on"-kysymyksiä.

Merkityksellisyyden kokemusta korona-aikana koskevan tutkimuksen kohdemaina ovat olleet Suomi, Puola, Italia ja Espanja, hyvin erilaiset maat, ja niistä vielä Suomi vähän omanlaisena. Omanlaisena sikäli, että koronapandemia ei koskenut Suomeen niin vakavasti kuin muihin tutkimusmaihin, varsinkaan Italiaan. Mutta kun etsitään merkityksen kokemuksia, niin Puolassa, Italiassa ja Espanjassa vaikuttaa syvällä katolinen traditio, jonka vaikutus ei tunnu pelkästään uskonnollisessa asennoitumisessa, vaan elämän kokonaisuudessa. 
Suomi on näistä maista todella omanlaisensa siinä mielessä, että täällä vaikuttaa luterilainen traditio. Uusimman ajan kirkkohistorian emeritusprofessori Eino Murtorinne on Kotimaa-lehden haastattelussa 19.11.2020 sanonut, että protestanttisen kristillisyyden ongelmaksi on osittain muodostunut ajankohtaisuuden vaatimus, kun uskonto perinteisesti on edustanut pysyvää ja muuttumatonta. Protestanttiset kirkot ovat jääneet muutoksen vangeiksi. Samalla kun Suomessa luterilainen kirkko pyrkii uudistumaan ja ajankohtaistumaan, niin esimerkiksi media aina vain leimaa sen menneisyyteen kuuluvaksi.

Ei ole mikään sattuma, että Saarelaisen esille tuomassa eurooppalaisessa arvotutkimuksessa (EVS) suomalaisten uskonnollisen aktiivisuuden prosentit ovat lähes kautta linjan pienemmät kuin Puolassa, Italiassa ja Espanjassa. Suomessa on vaikuttanut myös luterilaisen kirkon sisällä reformaation toisesta haarasta, kalvinilaisuudesta vaikutteita saanut herätyskristillisyys, johon kuuluu ajatus kristillisyydestä uskovan ihmisen omakohtaisena ratkaisuna eikä niinkään liittymisenä kirkon yhteiseen uskoon ja tuhatvuotiseen traditioon kasteen ja ehtoollisen sakramenttien kautta. Suomalaisessa kristillisyydessä todella on ollut jännite uskon henkilökohtaisuuden vaatimuksen ja kirkon yhteiseen uskoon liittymisen välillä. Pitkän kirkon nuorisotyön ja nuorisodiakonian uran tehnyt pappi Kimmo Virtanen eläkkeelle jäädessään 1980-luvulla sanoitti tämän osuvasti:"Kirkon yhteinen usko kantaa silloinkin, kun oma usko on vähän niin ja näin.”

Mielenkiintoinen poikkeus EVS:ssa kuitenkin löytyy. Suomalaisista $54 \%$ piti itseään uskonnollisina, mutta espanjalaisista vain 51 \%. Italiassa ja Puolassa luvut olivat korkeammat. Espanjan kielessä adjektiivia "uskonnollinen", religioso, käytetään myös substantiivina. Ihminen, jonka sanotaan olevan religioso tai religiosa on pappi, munkki tai nunna, luostariveli tai luostarisisar, siis uskonnolliseen elämänmuotoon sitoutunut. Vaikka sanaa "uskonnollinen" käytetään myös arkikielessä ihmisen uskonnollista asennetta luonnehtivana adjektiivina, oman stipendiaattiopiskeluaikani kokemuksen mukaan espanjalaisilla on hyvin korkea kynnys nimittää itseään uskonnollisiksi, tosin hiukan eri syistä kuin suomalaisilla. Toisaalta tietysti sekularisoitumiskehitystä tapahtuu katolisissakin maissa, ja sillä on varmasti osuutensa uskonnollisuutta kuvaaviin prosenttilukuihin, mutta tällaista suomalaisesta traditiosta poikkeavaa kielenkäyttöä ei voi jättää huomiotta.

Kun tarkastellaan merkityksellisyyden kokemusta koronaviruksen tai muun kriisin aikana, nousee väistämättä esiin kysymys arvoista. Perinteisesti 
filosofisessa kielenkäytössä ihmisen elämäntodellisuus jaetaan faktoihin ja arvoihin. Faktat kertovat, mitä ja miten asiat ovat, ja kun puhutaan siitä, miten asioiden pitäisi olla, puhutaan arvoista. Voi olla, että sellaista asioiden tilaa, jota arvostamme, emme koskaan saavuta, mutta pidämme sitä niin arvokkaana, että mielestämme sitä kannattaa tavoitella.

Yksi perinteinen tapa luokitella arvot on jako yhtäältä arvo-objektivismiin ja arvosubjektivismiin ja toisaalta jako arvo-objektivismiin ja arvorelativismiin. Voimme ajatella, että arvot, kuten henkiset, taloudelliset tai materiaaliset arvot ovat olemassa aina ja kaikkialla, ihmisten kokemuksista riippumatta. Tällainen ajattelu on arvo-objektivismia. Arvorelativisti voi ajatella vähän samaan tapaan, mutta niin, että yksi pitää yhtä ja toinen toista arvokkaampana, ja eri aikakausina ja eri tilanteissa arvot voivat vaihdella. Arvosubjektivisti taas ajattelee voivansa valita itselleen sopivan tuntuiset arvot ja hylätä toiset, ja arvokonstruktivisti taas ajattelee voivansa jopa muokata tai rakentaa itse omat arvonsa. (Arvojen luokittelusta ks. esim. Purjo, 2014).

Merkityksellisyyden kokemusta korona-aikana on tutkittu muun muassa väitteellä"On olemassa arvoja ja ihanteita, joita pidän kiistattoman varmoina". Tähän väittämään liittyi täysin peräti 52,2\% kyselyyn vastanneista suomalaisista. Tämä väite ilmaisee arvo-objektivistista ajattelua, kun se alkaa sanoilla "on olemassa..." Siinä puhutaan kiistattoman varmoina pidetyistä arvoista, jotka siis ovat olemassa ihmisen kokemuksesta riippumatta. Tämä tutkimustulos on kiinnostava, sillä yleisesti ajatellaan, että nyt elettäisiin arvosubjektivismin ja arvorelativismin aikaa, mikä tarkoittaa, että arvojen uskottaisiin olevan subjekti- ja kulttuurisidonnaisia ja niiden totuus tai epätotuus määräytyisi sen mukaan, mitä kukin yksilö pitää arvokkaana. Subjektivistisesti ajatellut arvot eivät ole varmoja eivätkä erehtymättömiä. Puhe "henkilökohtaisista" arvoista on tyypillistä arvosubjektivismia.

Koronakriisi on globaali kriisi. Sitä ei pääse pakoon mihinkään maailman kolkkaan. Se koettelee kaikkia ihmisiä, elivätpä he missä tahansa. Juuri tähän tilanteeseen yhdistettynä väite "on olemassa arvoja ja ihanteita, joita pidän kiistattoman varmoina" ilmaisee ajatusta, että kiistattoman varmat arvot ovat olemassa ihmisten kokemuksista riippumatta, että nämä eivät ole minun itseni valitsemia henkilökohtaisia arvoja, vaan ne koskettavat kaikkia, ja niiden välityksellä rakentuu myös yhteys eri ihmisten ja ihmisryhmien välille.

Vanhat suuret kirkot liittyvät arvojen ja etiikan opetuksessaan luonnollisen moraalilain perintöön. Tämän opetuksen mukaan ihmiset eivät ole luon- 
nostaan hyveellisiä, mutta eivät aivan pahojakaan, ja pystyvät langenneinakin tekemään hyvää toisilleen. Arvojen sisäisenä kompassina toimii omatunto. Luonnollinen moraalilaki näyttää oikeat elämää suojelevat arvot ja ohjaa myös omaatuntoamme niin, että tunnemme ne myös omiksi arvoiksemme. (Luonnollinen moraalilaki, 2021)

Vatikaanin toisen konsiilin asiakirjasta Gaudium et spes, suomeksi toimitettuna "Kirkko nykypäivän maailmassa" - olkoonkin että se nykypäivä oli vuonna 1967- sanotaan: "Omantunnon syvyydestä ihminen löytää lain, jota hän ei itse anna itselleen, vaan jota hänen täytyy totella. Sen ääni kutsuu häntä aina rakastamaan ja tekemään hyvää sekä välttämään pahaa, ja silloin kun on välttämätöntä, kaikuu hänen sydämessään: tee tätä, vältä tuota.” (Gaudium et spes, 2006).

Koronapandemian koetellessa koko maailmaa korostuu eettisen kasvatuksen, arvokasvatuksen, katsomuskasvatuksen ja uskonnollisen kasvatuksen tehtävä myönteistä elämänvoimaa luovana tekijänä.Liittyminen luonnollisen moraalilainperintöön antaa perustan kasvatustyölle,jokaluouskoaja rakkauttajatuo ihmiset lähelle toisiaan silloinkin, kun turvavälit on pidettävä riittävän pitkinä.

Kommenttipuheenvuoro Suvi-Maria Saarelaisen esitykseen Merkityksellisyyden kokemus korona-aikana Diakonian ja kasvatuksen tutkimuspäivässä 26.11.2020

\section{Kirjallisuus}

Gaudium et spes. (2006). Gaudium et spes. Kirkosta nykymaailmassa. Pastoraalikonstituutio. Katolinen tiedotuskeskus. katolinen.fi. https://katolinen.fi/gaudium-etspes/ - Viitattu 15.3.2021.

Luonnollinen moraalilaki. (2021). Aamenesta öylättiin - kirkon sanasto. Helsinki: Kirk- kohallitus. Saatavissa: https://evl.fi/sanasto/-/glossary/word/Luonnollinen+moraalilaki - Viitattu 15.3.2021.

Purjo, T. (2014). Arvot ovat ihmisen toiminnan perusta. Tampere: Tampere University Press. 